\title{
Union Authorization Cards: Linden's Peacemaking Potential
}

The National Labor Relations Act ${ }^{1}$ has always sanctioned authorization cards as a means for employees to designate or select a bargaining representative. $^{2}$ Yet the circumstances in which an employer is required to bargain with a union which has an authorization card majority have varied over the past 25 years since the passage of the TaftHartley Act. ${ }^{3}$ Recently the Supreme Court agreed to hear two cases ${ }^{4}$ which present the question whether the existence of an authorization card majority by itself activates the employer's duty to bargain where other means to select a bargaining representative are available. This Note evaluates the policy underlying the use of authorization cards and the practical problems presented by their use. It suggests that the Supreme Court should not decide the ultimate issue of the use of the cards but should remand the cases to the National Labor Relations Board (NLRB) with instructions to develop rules for card use which are consistent with the Act's purpose. Finally, the Note proposes rules the NLRB should develop and the procedure it should follow when presented with an authorization card dispute.

\section{The Cards}

Authorization cards are generally of two types. The first type is the unambiguous, single purpose authorization card, by which the employee authorizes the union to act as his sole bargaining agent under the National Labor Relations Act. 5 The second type, the dual purpose card, requests a representation election, and also authorizes the union to act as the sole bargaining representative ${ }^{0}$ in much the same manner as the first type of card.

1. Act of July 5, 1935, ch. 372, 49 Stat. 449, as amended, Act of June 23, 1947, ch. 120, 61 Stat. 136, Act of Sept. 14, 1959, Pub. L. No. 86-257, 73 Stat. 541, codified in 29 U.S.C. $\$ \$ 151-88(1970)$.

2. See NLRB v. Gissel Packing Co., 395 U.S. 575 (1969); United Mine Workers v. Arkansas Oak Flooring, 35I U.S. 62 (1956); Franks Bros. v. NLRB, 321 U.S. 702 (1944); NLRB v. Remington Rand, 94 F.2d 862 (2d Cir.), cert. denied, 304 U.S. 576 (1938).

3. Act of June 23,1947 , ch. 120,6 I Stat. 136.

4. Linden Lumber Div., Summer \& Co., 190 N.L.R.B. 718, 77 L.R.R.M. 1305; Wilder Mfg. Co., 81 L.R.R.M. 1039, consolidated with Linden Lumber and rev'd sub nom. Truck Drivers Local 413 v. NLRB, 487 F.2d 1099 (D.C. Cir. 1973) cert. granted sub nom. Linden Lumber Div., Summer \& Co. v. NLRB, 94 S. Ct. 1967 (1974).

5. An example may be found in NLRB v. Cumberland Shoe Corp., 351 F.2d 917, 918 (6th Cir. 1965). See, e.g., Snow \& Sons, 134 N.L.R.B. 709 (1961).

6. See NLRB v. Cumberland Shoe Corp., 351 F.2d 917 (6th Cir. 1965). The dual purpose card is often mislcading. An employee who opposes the union may sign, believing he is only requesting an election. 
The events that precede unfair labor practice litigation over the use of authorization cards usually follow a common pattern. ${ }^{7}$ The union, either through an employee or through a full-time union organizer, starts an organizational drive in a particular bargaining unit. The union usually does not inform the employer of the drive, and occasionally it is able to keep the drive a secret until it actually presents its recognition demand. ${ }^{s}$ When the union has cards from a majority of the employees in an appropriate unit, it informs the employer of the majority and requests recognition and bargaining. ${ }^{9}$

Employer responses are varied. ${ }^{10}$ If the employer was aware of the drive, he may already have attempted some form of anti-union campaign. If he was not, he might initiate such a campaign after the bargaining request. In either case, he is likely to investigate union support on his own. Eventually, the employer may petition the Board for an election, ${ }^{11}$ not wishing to recognize a union on the sole basis of authorization cards; or he may tell the union to petition for an election, believing that the burden is on the union to demonstrate its majority status; ${ }^{12}$ or he may deny or ignore the union's request. ${ }^{13}$

Occasionally the union files an election petition with the Board at the same time that it presents its bargaining demand to the employers. ${ }^{14}$ If the union does so, the election will proceed, unless employer

7. See, e.g., NLRB v. Gissel Packing Co., 395 U.S. 575 (1969); Crawford Mfg. Co. v. NLRB, 386 F.2d 367, 369 (4th Cir. 1967); NLRB v. Swan Super Cleaners, Inc., 384 F.2d 609, 614 (6th Cir. 1967).

8. See, e.g., NLRB v. S.S. Logan Packing Co., 386 F.2d 562 (4th Cir. 1967); NLRB v. Swan Super Cleaners, Inc., 384 F.2d 609 (6th Cir. 1967); NLRB v. Gotham Shoe Mfg. Co., 359 F.2d 684 (2d Cir. 1966); NLRB v. Koehler, 328 F.2d 770 (4th Cir. 1964); Comment, Union Authorization Cards: $A$ Reliable Basis for an NLRB Order to Bargain?, 47 Texas L. Rev. 87, 89 (1968); Note, Union Authorization Cards, 75 Yale L.J. 805, 823-28 (1966).

9. An employer must "bargain collectively with the representatives of his employees, subject to the provisions of section 159 (a) ..." 29 U.S.C. $\$ 158(a)(5)$ (1970). Section 159 (a) provides that "representatives designated or selected for the purposes of collective bargaining by the majority of the employees ... shall be the exclusive representatives of all the employees . . . for the purposes of collective bargaining . . . "

10. Of course, the employer might simply recognize the union, but then unfair labor practice litigation would probably not occur.

11, See 29 U.S.C. $\$ 159$ (c)(1)(B) (1970).

12. See, e.g., Dayco Corp. v. NLRB, 382 F.2d 577, 578 (6th Cir. 1967).

13. See NLRB v. Gissel Packing Co., 395 U.S. 575, 594 (1969). Both the opinion and the transcript of the oral argument are ambiguous on whether an employer may say "no comment" or whether he must tell the union that he wants it to petition for an election. Transcript of Oral Argument on behalf of Petitioner at 3, 16, NLRB v. Gissel Packing Co., 395 U.S. 575 (1969).

14. Before Bernel Foam Prods. Co., 146 N.L.R.B. 1277, 56 L.R.R.M. 1039 (1964), the NLRB required a union to choose between an election and an unfair labor practice proceeding charging a refusal to bargain. Aiello Dairy Farms, 110 N.L.R.B. 1364 (1954). Although the change from Aiello has been criticized, Note, supra note 8, at 816, the new policy appears to be responsible for an increase in the number of elections stemming from authorization card disputes. See Gordon, Union Authorization Cards and the Duty to Bargain, 19 LAB. L.J. 201 (1968). 
unfair labor practices ${ }^{15}$ so disrupt "laboratory conditions"16 as to make the holding of a fair election improbable. ${ }^{17}$ If such disruption has occurred, the union generally withdraws its election petition or moves to have the election voided (if the unfair practices did not come to light until after the voting). It then files a refusal-to-bargain charge against the employer on the basis of the authorization card majority. Even without petitioning for an election, however, the union might still pursue a refusal-to-bargain charge against the employer, relying likewise on the card majority as the basis of its charge. ${ }^{18}$

In either case, trying a refusal-to-bargain charge requires the NLRB to determine whether a genuine majority of the employees indeed supported the union at the time when it presented its bargaining request to management. ${ }^{10}$ Such a determination from the evidence of the cards requires the NLRB to judge whether any of the cards should be invalidated because of the effects of union misconduct during the card drive, or because the cards on their faces would tend to mislead employees. ${ }^{20}$ If the NLRB finds that the union did have a majority,

15. The unfair labor practices usually involve: threats of reprisals or promises of benefits, or interrogation or surveillance of employees, violating 29 U.S.C. $\$ 158(a)(1)$ (1970), or discrimination in hiring, firing or laying-off employees because of their union activities, violating 29 U.S.C. $\$ 158(a)(3)$ (1970).

16. General Shoe Corp., 77 N.L.R.B. 124, 21 L.R.R.M. 1337 (1948).

17. Dal-Tex Optical Co., 137 N.L.R.B. 1782, 50 L.R.R.M. 1949 (1962). See 29 NLRB ANN. REP. 57.58 (1964).

18. 29 U.S.C. $\$ 158(a)(5)(1970)$. If the union that holds the card majority has truly been "designated or selected" by whatever means, including authorization cards, then the union has the right to a bargaining order from the NLRB when the employer refuses to bargain. This possibility of two remedies (election and a refusal-to-bargain charge) was the major factor prompting the dissent in and criticism of the NLRB's Bernel Foam decision, I46 N.L.R.B. 1277, 1288, 56 L.R.R.M. 1039, 1043 (1964) (Leedom, concurring in part and dissenting in part); Note, supra note 8, at 816 .

19. NLRB v. Gissel Packing Co., 395 U.S. 575, 614 (1969); Christensen \& Christensen, Gissel Packing and "Good Faith Doubt": The Gestalt of Required Recognition of Unions under the NLRA, 37 U. CHI. L. REv. 41I, 422 (1970); Welles, The Obligation to Bargain on the Basis of a Card Majority, 3 GA. L. REv. 349, 357-59 (1969). See Rains, Authorization Cards as an Indefensible Basis for Board Directed Union Representation Status: Fact and Fancy, 18 LAB. L.J. 227, 230 (1967). Both Bok and the NLRB have stated that an order to bargain may be appropriate even where the union never had a majority, if the employer's unfair labor practices are of "such a nature that their coercive effects cannot be eliminated by the application of traditional remedies," NLRB v. S.S. Logan Packing Co., 386 F.2d 562, 570 (4th Cir. 1967); Bok, The Regulation of Campaigns in Representation Elections Under the National Labor Relations Act, 78 Harv. L. Rev. 38, $134-39$ (1964). See NLRB v. Gissel Packing Co., 395 U.S. 575, 613-14 (1969); J.C. Penney Co., Inc. v. NLRB, 384 F.2d 479, 485-86 (10th Cir. 1967); United Steelworkers of America v. NLRB, 376 F.2d 770 (D.C. Cir. 1967).

20. See, e.g., NLRB v. S.S. Logan Packing Co., 386 F.2d 562 (4th Cir. 196i); Levi Strauss \& Co., 172 N.L.R.B. 732, 68 L.R.R.M. 1338 (1968); Cumberland Shoe Corp., 144 N.L.R.B. 1268 (1963); Snow \& Sons, 134 N.L.R.B. 709 (1961). The NLRB's policy, articulated in Snow \& Sons and refined in Cumberland Shoe, has been that a few bad apples will not spoil the bunch: even where a pattern of union misrepresentation or coercion exists, the NLRB will invalidate only those cards which are proved to have been signed under threats or misapprehensions of the card's purpose. Snow \& Sons, 134 N.L.R.B. at 710. 
it may then issue a bargaining order. ${ }^{21}$ However, in a case where an election petition had been filed, if the employer's unfair labor practices were not so serious as to make a fair election improbable, the NLRB may order an election to proceed, or it may order a rerun election. ${ }^{22}$

\section{The National Labor Relations Act}

An important purpose of the National Labor Relations Act has been to facilitate industrial democracy ${ }^{23}$ by safeguarding employees' rights to organize and to choose a bargaining representative. ${ }^{24}$ The Act has established procedures which bind an employer to bargain with the chosen representative, if the employees decide to organize. ${ }^{25}$ Boardconducted elections have provided the "preferred route" for either the designation of a bargaining representative or the expression of a decision against unionization. ${ }^{26}$ Nevertheless, the Act has always sanctioned other methods for the employees to express their choice. ${ }^{27}$

$N L R B$ v. Gissel Packing Co. validated authorization cards as one such alternate route. ${ }^{28}$ The union in Gissel requested the employer to bargain based on its majority status as demonstrated by cards rather than an election. The employer refused, meanwhile engaging in misconduct which precluded the holding of a fair election. The Board

21. See, e.g., NLRB v. Gissel Packing Co., 395 U.S. 575, 614 (1969).

22. See, e.g., Aaron Bros. Co., 158 N.L.R.B. 1077 (1966).

23. See Louis D. Brandeis, Statement, U.S. Comm'N on Industrial Relations, Final Report, S. Doc. No. 415, 64th Cong., Ist Sess. 7659-60 (1916). See also id. at 62-64.

24. See 29 U.S.C. $\$ \S 157,158$ (1970), which demonstrate a congressional purpose to protect an employee's right of free choice to decide whether to join a union, by preventing employers and unions from exerting economic pressure on employees to discourage or encourage unionization.

25. See 29 U.S.C. $\$ 159$ (1970) (establishing NLRB conducted elections); 29 U.S.C. $\$ 160$ (1970) (establishing procedures to adjudicate alleged violations of 29 U.S.C. $\S 158$ $(1970))$.

26. 29 U.S.C. $\$ 159$ (a) (1970); NLRB v. Gissel Packing Co., 395 U.S. 575, 596 (1969); Aaron Bros., 158 N.L.R.B. 1077 (1966).

27. NLRB v. Gissel Packing Co., 395 U.S. 575, 595.600 (1969). There remained little doubt, even prior to Gissel, that an employer had a duty to bargain with a union that had been "designated or selected by a majority of the employees in an appropriate bargaining unit," 29 U.S.C. $\$ 159$ (a) (1970), even though the union had not been so designated through a Board election. United Mine Workers v. Arkansas Oak Flooring, 351 U.S. 62 (1956). See Franks Bros. v. NLRB, 321 U.S. 702 (1944).

The courts interpreted the rule to apply whenever a union presented "convincing evidence of majority support." NLRB v. Dahlstrom Metallic Door Co., 112 F.2d 756, 757 (2d Cir. 1940). However, as what constitutes "convincing evidence" has never been defined, the NLRB's practice since Aaron Bros., 158 N.L.R.B. 1077 (1966), has been to allow an employer confronted with a bargaining demand based on cards to request an election unless he has prevented, by his own conduct, the holding of a fair election. NLRB v. Gissel Packing Co., 395 U.S. at 592.93.

28. NLRB v. Gissel Packing Co., 395 U.S. 575, 601 (1969). In overruling the Fourth Circuit, the Supreme Court deferred to the Board's practice. Id. at 602-03. 
ordered the employer to bargain, and the Supreme Court held that such an order, grounded on the cards, was valid where a fair election was unlikely. ${ }^{29}$ However, the Court left it to the NLRB to decide when a bargaining order based on authorization cards would best effectuate the purposes of the Act. ${ }^{30}$ The Board's basis for making this decision in individual cases has evolved over the past 40 years, as changing ideas and new industrial practices have required new methods to protect employee free choice.

Under the Wagner Act, ${ }^{31}$ the Board could certify a union whenever the union represented a majority of the employees in an appropriate bargaining unit. ${ }^{32}$ Elections were not required, and employers were not permitted to petition for an election. ${ }^{33}$ Unions frequently used authorization cards as a means of evidencing majority support. ${ }^{34}$ Against this background, the Supreme Court decided Franks Bros. Co. v. NLRB. ${ }^{35}$ The NLRB had ordered an employer to bargain with a union which lost its majority after the employer wrongfully refused to bargain with it. The Supreme Court held that the NLRB was within its statutory authority, ${ }^{36}$ noting that the bargaining order was intended to deter employer misconduct in order to protect employee rights. ${ }^{37}$

Three years after Frank Bros., Congress passed the Taft-Hartley Act, ${ }^{38}$ which gave an employer a right to petition for an election in certain circumstances. ${ }^{39}$ In Joy Silk Mills, ${ }^{40}$ the leading early authorization card case under Taft-Hartley, the NLRB held that an employer confronted with a bargaining demand based on authorization cards

29. Id. at $580-84,610-15$.

30. Id. at $610,614-15$.

31. Act of July 5, 1935, ch. 372, 49 Stat. 449.

32. 29 U.S.C. $\$ 159$ (c) $(1970)$.

33. 29 U.S.C. $\S 159(\mathrm{C})(\mathrm{I})(\mathrm{B})(1970)$, allowing an employer petition, was not added until passage of the Taft-Hartley Act, ch. 120, 61 Stat. 136. The NLRB did permit employers presented with bargaining demands from two unions to petition for an election. See NLRB v. Gissel Packing Co., 395 U.S. 575, 599 \& nn.15, 16 (1969).

34. See, e.g., Franks Bros. Co. v. NLRB, 321 U.S. 702 (1944); NLRB v. Remington Rand, 94 F.2d 862 (2d Cir.), cert. denied, 304 U.S. 576 (1938).

35. 321 U.S. 702 (1944), aff'g 137 F.2d 989 (1st Cir. 1943), enforcing 44 N.L.R.B. 898 (1942).

36. 321 U.S. at 705. The union initially had authorization cards from a majority of the employees. The employer refused to bargain, so the union petitioned for an clection. The union lost, but the NLRB found the employer guilty of violations of 29 U.S.C. $\$ \S 158(a)(1), 158(a)(5)$ (1970), voided the election, and issued a bargaining order. Even though the union had lost its original majority due to employee turnover, the Court held that the bargaining order was appropriate.

37. 321 U.S. at 705.

38. Act of June 23, 1947, ch. 120,61 Stat. 136 .

39. 29 U.S.C. $\$ 159$ (c)(1)(B) (1970).

40. 85 N.L.R.B. 1263 (1949), enforced, 185 F.2d 732 (D.C. Cir.), cert. denied, 341 U.S. 914 (1951). 
could petition for an election only if he entertained a "good faith doubt" of the union's majority. ${ }^{41}$ The right to petition was limited so that an employer who had no bona fide doubts about the union's majority status was not permitted to gain time during which to dissipate the union's majority by invoking the NLRB's election process. ${ }^{42}$ The good faith test required the NLRB to evaluate the employer's actions to determine his subjective state of mind at the time of the petition for an election. Employer unfair labor practices that tended to undermine the union's support were taken as evidence that the employer lacked good faith doubt of the union's majority status. ${ }^{43}$ In effect, the burden was on the employer to prove good faith.

In 1965, the Board made it easier for the employer to meet the good faith test. In John P. Serpa, Inc. ${ }^{44}$ five of the employer's seven salesmen signed authorization cards. The union presented a bargaining demand, then filed a complaint when the employer refused to bargain. Placing the burden of proving the employer's bad faith on its own General Counsel for the first time, the NLRB held that the burden had not been met and dismissed the complaint. ${ }^{45}$

Then, at oral argument in NLRB v. Gissel Packing Co., the Board announced that it had abandoned altogether the good faith test of Joy Silk, and would permit an employer to insist on an election before recognizing the union. ${ }^{4}$ The Board articulated only three limits on the employer's broad prerogative: if the employer was guilty of unfair labor practices that would prevent the holding of a fair election, if he "knew, through a personal poll for instance, that a majority of employees supported the union," 47 or if he solely wished to contest the appropriateness of the bargaining unit, then he had a duty to bargain with the union and could not insist on an election. If one of the latter two limits applies, the employer has in effect conceded that the cards represent a true underlying union majority. Thus, the protection of

41. 85 N.L.R.B. at 1264 .

42. 185 F.2d at 741 .

43. Aaron Bros. Co., 158 N.L.R.B. 1077, 1079 (1966). This inference is dubious. An employer might well campaign against a union or interrogate employees even where he does have a genuine doubt of the union's majority status. See, e.g., NLRB v. S.S. Logan Packing Co,, 386 F.2d 562, 568 (4th Cir. 1967).

44. 155 N.L.R.B. 99 (1965).

45. Id. at 100 .

46. 395 U.S. 575,594 (1969).

47. Id. (emphasis in original). The Board has used the phrase "independent knowledge" to describe those situations where the employer knows, independently of the cards, that the union represents a majority of his employees. Snow \& Sons, 134 N.L.R.B. 709 (1961). 
employee free choice expressed through authorization cards remains an important goal.

In moving away from the good faith test, the NLRB's policy change in Gissel ${ }^{48}$ contributes to that goal in another sense. The subjective issue of the employer's state of mind in a refusal to bargain charge, as Harry $H$. Rains has argued, is simply "of no importance in determining and giving effect to the employee's free choice." 49 The central issue in determining whether the employer has a duty to bargain should be whether the union has the support of an objectively determined majority of his employees. ${ }^{50}$ That is, an employer's duty to bargain should depend upon whether the majority of employees have selected a union, not upon the reasons the employer might have had for refusing to bargain.

\section{The Unanswered Question in Gissel}

The NLRB's abandonment of the good faith test, announced at oral argument in Gissel, apparently applied to all authorization card cases. The only issue actually addressed by the Court, however, was whether the issuance of a bargaining order on the basis of a card majority was an appropriate and authorized remedy under the Act in a case where employer unfair labor practices had precluded the holding of a fair election. Gissel held only that the cards are not so inherently unreliable that they may never be used to support a bargaining order. ${ }^{51}$ The Supreme Court has recently granted certiorari in two cases where a fair election is still possible. ${ }^{2}$ The issue thus presented is whether

48. The change was not sudden, but was merely announced during oral argument as the culmination of a gradual shift in Board policy during the 1960's. Transcript of Oral Argument on behalf of Petitioner at 9-10, NLRB v. Gissel Packing Co., 395 U.S. 575 (1969).

49. Rains, supra note 19, at 229-30. Issues that have nonetheless crept into authorization card decisions include: the employer's "good faith doubt" of the union's majority status, Joy Silk Mills, 85 N.L.R.B. 1263, 1264 (1949), enforced, 185 F.2d 732 (D.C. Cir.), cert. denied, 341 U.S. 914 (1951); employer "independent knowledge," Snow \& Sons, 134 N.L.R.B. 709,710 (1961); and employer "willingness to have majority status determined by an election," Truck Drivers Local 413 v. NLRB, 487 F.2d 1099, 1111 (D.C. Cir.), cert. granted sub nom. Linden Lumber Div., Summer \& Co. v. NLRB, 94 S. Ct. 1967 (1974).

50. See 29 U.S.C. $\$ \S 158(\mathrm{a})(5), 159$ (a) (1970), quoted in note 9 supra. In ILGWU v. NLRB, 366 U.S. 731 (1961) (commonly known as Bernhard-Altmann), the Court rejected a defense of good faith in a proceeding involving alleged recognition of a minority union, 29 U.S.C. $\$ 158($ a)(2) (1970). It held that the actual existence of a union majority was a sine qua non of recognition by the employer under the Act. Though a different section of the Act is involved in a refusal-to-bargain proceeding, 29 U.S.C. $\$ 158(a)(5)$ (1970), Bernhard-Altmann may suggest the importance of an objective test there as well, and the irrelevance of the employer's state of mind.

51. 395 U.S. at 595, 601 n.18. See Christensen \& Christensen, supra note 19, at 421-24.

52. Linden Lumber Div., Summer \& Co. v. NLRB, cert. granted, 94 S. Ct. 1967 (1974) (consolidated for argument with NLRB v. Truck Drivers Local 413). 
cards provide a test of employee sentiment so objective and workable that a card majority requires a bargaining order when neither the employer nor the union has petitioned for an election. ${ }^{53}$

In both Linden Lumber Division, Summer is Co.54 and Wilder Manufacturing Co.,55 the union demanded recognition and bargaining based on a card majority. The employer refused, without committing any unfair labor practices that would tend to dissipate the union's support or prevent the holding of a fair election. The union filed a refusal-to-bargain charge, but the NLRB would not issue a bargaining order. Moving still further away from any examination of the employer's state of mind or subjective motivation, the NLRB rejected the "independent knowledge" test. 50 That test had provided one limit to the employer's prerogative to insist upon an election when presented with a card-based bargaining demand. ${ }^{57}$ The Board will now recognize authorization cards only where the employer has agreed to be bound by them. ${ }^{58}$ In addition, it has freed the employer from any

53. Petitioner's Brief for Certiorari at 3, 6-7, Linden Lumber Div., Summer \& Co. v. NLRB, cert. granted, 94 S. Ct. 1967 (1974); Petitioner's Brief for Certiorari at 2, 11-12, NLRB v. Truck Drivers Local 413, cert. granted, 94 S. Ct. 1967 (1974). The question is whether atthorization cards constitute "convincing evidence of majority support," NLRB v. Dahlstrom Metallic Door, Inc., 112 F.2d 756, 757 (2d Cir. 1940). If they do, then the employer should be required to bargain. The unions, however, contend that because there were also recognitional strikes, the cards are not the only evidence in these cases, and that the Court should allow the NLRB to consider whether strikes and cards together constitute convincing evidence. Respondent's Brief in Opposition at 7-9, Linden Lumber Div., Summer \& Co. v. NLRB, supra. In contrast, the NLRB in Linden Lumber Div., Summer \& Co., 190 N.L.R.B. 718, 720, 77 L.R.R.M. 1305, 1308 (1971), claimed that the question was whether, absent election interference, an cmployer who insists on an election must himself initiate the petition. The dissent mistakenly agreed that this was the question left open in Gissel, but correctly argued that the issue was not present in this case.

54. 190 N.L.R.B. 718, 77 L.R.R.M. 1305 (1971).

55. 81 L.R.R.M. 1039 (1972) (Second Supplemental Decision and Order).

56. See note 47 supra.

57. Linden Lumber Div., Summer \& Co., 190 N.L.R.B. 718, 722, 77 L.R.R.M. 1305, 1309-10 (1971) (Fanning \& Brown, dissenting). The Board redefined "independent knowledge," limiting the term to the case where the employer has explicitly agreed to authentication of the authorization cards by an impartial third party. The NLRB emphasized that the employer and the union had never agreed on any legal means other than an election to determine majority status. It distinguished its decision in Snow \& Sons, 134 N.L.R.B. 709 (1961), as involving "breach of [an] agreement to permit majority status to be determined by other than a Board election," as well as independent knowledge. 190 N.L.R.B. at 720, 77 L.R.R.M. at 1309. On review, the D.C. Circuit questioned this interpretation: "[I]t was represented to the Supreme Court in Gissel that the facts of Snow \& Son [sic] laid the predicate for a finding of independent knowledge, not that a finding of 'independent knowledge' was restricted to such facts." Truck Drivers Local 413 v. NLRB, 487 F.2d 1099, $1108-09$ (D.C. Cir. 1973) (footnote omitted).

58. The NLRB's approach relegates the cards to three relatively minor functions: (1) to protect an employer, should he wish to recognize the union, from charges under 29 U.S.C. \$ 158(a)(2) (1970), see ILGWU v. NLRB, 366 U.S. 731 (1961) (commonly known as Bernhard-Altmann); (2) to protect the union, as the next best method of determining majority status, when the election process has failed; and (3) to allow the union to make the 30 percent showing necessary for an election petition, see 1969 CCH GUidebOOK TO LAB. ReL., If 402.4. 
obligation to respond either to cards or to other objective evidence of majority support. ${ }^{50}$

Reviewing these two NLRB decisions in Truck Drivers Local 413 v. $N L R B,{ }^{60}$ the court of appeals held "that if 'independent knowledge' is to be restricted, some alternative must be put in its place to prevent an employer's deliberate flouting and disregard of union cards without rhyme or reason." ${ }^{61}$ The court remanded the cases to the NLRB to reconsider what option, consistent with the statute, it might wish to follow. ${ }^{62}$ The opinion thus protects the employees' choice as expressed on the cards, but, as the quoted passage indicates, it reinstates some inquiry into the employer's subjective state of mind. ${ }^{63}$ It thus conflicts with Gissel's implicit approval of the Board's abandonment of good faith as a standard for defining the duty to bargain. ${ }^{64}$ The court would, in effect, have the Board reenter "the good faith thicket of Joy Silk" "Bs from which it extricated itself in Linden Lumber. ${ }^{66}$

Instead, the remand instructions should have required the NLRB to develop and apply some objective means of determining employee sentiment, not employer state of mind, and to hold the employer to the results of that determination. ${ }^{67}$ Certainly, such a test need not be limited to authorization cards. ${ }^{68}$ However, in the cases now before the Supreme Court ${ }^{60}$ cards provided the primary evidence of union sup-

59. In Wilder Mffg. Co., 81 L.R.R.M. 1039 (1972), a majority of the employees had engaged in a recognitional strike. Nevertheless, the Board released the employer from any obligation to bargain absent his consent to having majority status demonstrated by a method other than a Board election.

60. 487 F.2d 1099 (D.C. Cir. 1973).

61. Id. at 1113 .

62. Id. The court suggested one possible option: require the employer either to recognize the union or to petition for an election himself when presented a card-based bargain demand. $I d$. at 1111 \& $n .47$.

63. The opinion concluded that if the NLRB was to abandon the " independent knowledge' or 'good faith' test .... the employer must be put to some other kind of test to evidence good faith." Id. at 1113 .

64. See pp. 169495 \& note 49 supra.

65. Linden Lumber Div., Summer \& Co., 190 N.L.R.B. 718, 77 L.R.R.M. 1305 (1971); Joy Silk Mills, 85 N.L.R.B. 1263, 24 L.R.R.M. 1548, enforced, 185 F.2d 732 (D.C. Cir.), cert. denied, 341 U.S. 914 (1951).

66. 190 N.L.R.B. 718, 77 L.R.R.M. 1305 (1971).

67. An objective test of the union's status is preferable to tests of the employer's state of mind when he refused to bargain. Not only does it protect employee rights, but it is also consistent with the NLRB's reason for eliminating the independent knowledge and willingness tests-practical difficulties of administration. Linden Lumber Div., Summer \& Co., 190 N.L.R.B. 718, 77 L.R.R.M. 1305, 1309 (1971); Wilder Mfg. Co., 81 L.R.R.M. 1039, 1040 (1970).

68. The Supreme Court in Gissel recognized that a bargaining obligation may arise without an election, but did not hold that cards are the only possible evidence of union support adequate to create a bargaining obligation. The Court specifically referred to other evidence, such as "a union-called strike or strike vote," 395 U.S. at 597 (footnote omitted).

69. In Linden Lumber, there was a recognitional strike, and in Wilder Mfg. Co., there was other evidence of union support. Nevertheless, this evidence is only supportive; the cards are the central focus of the cases. 
port, and the unanswered question in Gissel relates primarily to the cards as well. ${ }^{70}$

\section{The Reliability and Practicability of the Cards}

Union authorization cards are inherently problematic. Whether the card solicitor is an employee or a full-time union organizer, the card drive may acquire a bandwagon effect more readily than an election. There is a danger of threats or promises from the solicitor, ${ }^{71}$ especially if the solicitor is not versed in union affairs and is unaware that it is illegal for the union to change seniority or job rights arbitrarily as reward or punishment for union support. ${ }^{72}$ Physical threats may also be present..$^{73}$ The potential for misrepresentation is great, ${ }^{74}$ and the employer has no opportunity to counter any union statements. ${ }^{75}$ Employees may thus be deprived of the ability to make an informed, reasoned, and free decision regarding unionization and the choice of bargaining representative, and their rights under the Act to self-determination and industrial democracy may be infringed.78 Lastly, the employee has a difficult time changing his mind before the bargaining demand is made, because of the difficulty in asking the solicitor to return his card. ${ }^{77}$ The result is that the employee may not favor unionization or the particular bargaining representative at the time the union claims a majority and makes a bargaining demand. ${ }^{78}$

70. 395 U.S. $575,595,601$ n.18.

71. NLRB v. S.S. Logan Packing Co., 386 F.2d 562, 565-66 (4th Cir. 1967); NLRB v. Gotham Shoe Mfg. Co., 359 F.2d 684, 698 (2d Cir. 1966) (Timbers, J., concurring and dissenting); Rains, supra note 19, at 231; Note, supra note 8, at 825 .

72. See 29 U.S.C. $\$ 158(\mathrm{~b})(2)(1970)$.

73. NLRB v. Gissel Packing Co., 395 U.S. 575 (1969). See Linden Lumber Div., Summer \& Co., 190 N.L.R.B. 718 (1971) (Trial Examiner's Decision).

74. The solicitor may misrepresent not only the purpose of the cards, but also potential benefits from, and arguments for, unionization. See, e.g., Crawford Mfg. Co. v. NLRB, 386 F.2d 367, 370 (4th Cir. 1967); NLRB v. Swan Super Cleaners, Inc., 384 F.2d 609, 615 (6th Cir. 1967); Dayco Corp. v. NLRB, 382 F.2d 577, 581-82 (6th Cir. 1967); NLRB v. S.E. Nichols Co., 380 F.2d 438, 442-44 (2d Cir. 1967); Engineers \& Fabricators, Inc. v. NLRB, 376 F.2d 482, 486-87 (5th Cir. 1967); NLRB v. Gotham Shoe Mfg. Co., 359 F.2d 684, 686 (2d Cir. 1966); NLRB v. Cumberland Shoe Corp., 351 F.2d 917 (6th Cir. 1965); NLRB v. Koehler, 328 F.2d 770, $772-73$ (7th Cir. 1965); Snow \& Sons, 134 N.L.R.B. 709 (1961).

75. See Shuman, Requiring a Union to Demonstrate Its Majority Status by Means of an Election Becomes Riskier, 16 LAB. L.J. 426, 429 (1965).

76. See id. The employees may face economic or physical threats, contrary to the policy of the Act that the organizational arena is to be free from all forces save persuasion. Lesnick, Establishment of Bargaining Rights Without an NLRB Election, 65 Mich. L. Rev. 851, 867 (1967). See C. Summers \& H. Wellington, Labor Law 436-38, 472-73 (1968).

77. NLRB v. S.S. Logan Packing Co., 386 F.2d 562, 566 (4th Cir. 1967).

78. The card process may be inaccurate, for the reasons noted above, in its reflection of employee sentiment. In a speech in 1962, NLRB Chairman McCulloch presented the following statistics: 
Since the employer is often unaware of the card drive until the union presents the cards and demands recognition and bargaining, ${ }^{79}$ he loses any opportunity to argue against unionization or against the particular union. ${ }^{80} \mathrm{He}$ loses as well some degree of industrial peace; an unsuccessful election bars another election for at least one year, while an unsuccessful card drive bars neither a subsequent election nor a card drive. ${ }^{81}$ Moreover, because a card drive is often a closely guarded secret and is conducted by only one union, rival unions are virtually excluded from participation in the campaign.

Thus, compared with the rigor of the requirements of laboratory conditions in an election, ${ }^{82}$ a card drive may fail to achieve the goal of determining whether the union is "designated or selected by a majority of the employees." 83 In addition, the card process may postpone rather than expedite determination of majority status. ${ }^{84}$ When the issue of majority support is eventually tried, the trial examiner faces the absurd task of determining employee sentiment as it existed months or years before the hearing, a process even less reliable than the highly suspect cards.

On the other hand, the cards do have some positive value in protecting union and employee rights. If an employer has disrupted or voided an election by his own misconduct, he should not be able to escape his bargaining duty. ${ }^{85}$ Where unfair labor practices have been committed, the only available means of determining employee senti-

In 58 elections, the unions presented authorization cards from 30 to 50 percent of the employees; and they won 11 or $19 \%$ of them. In 87 elections, the unions presented authorization cards from 50 to 70 percent of the employees; and they won 42 or $52 \%$ [sic] of them. In 57 elections, the unions presented authorization cards from over $70 \%$ of the employees; and they won 42 , or $74 \%$ of them.

McCulloch, A Tale of Two Cities: or Law in Action in ABA SECTION of LAB. ReL. LAw, 1962 Proc. 17.

79. See note 8 supra.

80. Cf. Lesnick, supra note 76, at 855-59; Transcript of Oral Argument on behalf of Petitioner at 3, 12-13, NLRB v. Gissel Packing Co., 395 U.S. 575 (1969).

81. Conren, Inc. v. NLRB, 368 F.2d 173 (7th Cir. 1966); 29 U.S.G. § 159(c)(3) (1970).

82. General Shoe Corp., 77 N.L.R.B. 124, 21 L.R.R.M. 1337 (1948).

83. 29 U.S.C. $\$ 159$ (a) (1970).

84. An election, even if contested, usually takes less than two months. Comment, Employer Recognition of Unions on the Basis of Authorization Cards: The "Independent Knowledge" Standard, 39 U. CHI. L. REv. 314, 325 n.48 (1972); 37 NLRB ANN. REP. 13 (1972) (median time of 45 days). In contrast, a refusal to bargain proceeding may take a year or more, NLRB v. Gissel Packing Co., 395 U.S. 575, 611 n.30 (1969) (median time of 388 days). Wilder Mfg. Co., 81 L.R.R.M. 1039 (1972), has not yet been resolved; the card drive took place in October 1965.

85. NLRB v. Gissel Packing Co., 395 U.S. 575 (1969); Franks Bros. v. NLRB, 321 U.S. 702 (1944). This assumes that the union did have a majority at one time that was destroyed by the employer's unlawful conduct. See NLRB v. Gissel Packing Co., 395 U.S. 575, 613-14 (1969); Welles, supra note 19, at 359-60. 
ment prior to the election may be the cards. ${ }^{86}$ Of course, employee views might have changed during a proper campaign, but the employer cannot be heard to complain about not being allowed to influence employee choice when he has abused the right. In such situations, cards provide the only alternative to employer victory. However unreliable, they surpass a void election in determining employee sentiment. ${ }^{87}$ As Gissel recognized, they cannot be wholly discounted.

The Board should therefore not preclude an employer from defending against a union recognition demand on the grounds that the union coerced or deceived the employees into signing the cards. The employer is the only party who could effectively raise an objection to such a violation of the employees' right of free choice. Indeed, the employer should be allowed to raise such a defense so that he may avoid violating another provision of the Act: he is prohibited from bargaining with a union that does not represent a majority of his employees. ${ }^{88}$ If the employees were coerced or deceived into signing union cards, the union coercion or deception vitiates employee consent, in much the same manner that employer coercion will invalidate a vote against unionization in a Board-conducted election. ${ }^{80}$

Employers typically raise the defense of union coercion or misrepresentation in a refusal-to-bargain proceeding involving authorization cards. ${ }^{90}$ Of course, this defense is also available to an employer after an election, ${ }^{91}$ requiring the same type of litigation. But whereas union coercion voids an entire election, ${ }^{92}$ union coercion or misrepresentation in a card drive invalidates only the cards of those proven to have been the subject of the misconduct. ${ }^{93}$ Needless to say, it is unlikely that every instance of union coercion in a card drive is detected, especially if the drive is kept secret. In contrast, an election is always a public affair. The card process therefore delays recognition

86. See NLRB v. Gissel Packing Co., 395 U.S. at 601 n.18; NLRB v. Sehon Stevenson \& Co., Inc., 386 F.2d 551, 554, 556 (4th Cir. 1967) (Sobeloff, J., concurring specially); Sheinkman, Recognition of Unions Through Authorization Cards, 3 GA. L. REv. 319, 328-29 (1969).

87. NLRB v. Gissel Packing Co., 395 U.S. 575 (1969). This feature has prompted many cases and comments to favor a bargaining order in these cases. See note 86 supra; Truck Drivers Local 413 v. NLRB, 487 F.2d 1099 (D.C. Cir. 1973).

88. ILGWU v. NLRB, 366 U.S. 731 (1961) (Bernhard-Altmann); 29 U.S.C. $\$ 158(\mathrm{a})(2)$ (1970).

89. See notes 9,17 supra.

90. See, e.g., NLRB v. Cumberland Shoe Corp., 351 F.2d 917 (6th Cir. 1965).

91. See Dal-Tex Optical Co., 137 N.L.R.B. 1782, 50 L.R.R.M. 1949 (1962).

92. Id.

93. Cumberland Shoe Corp., 144 N.L.R.B. 1268, enforced, 351 F.2d 917 (6th Cir. 1965). Gissel explicitly approved the Sixth Circuit's decision. NLRB v. Gissel Packing Co., 395 U.S. 575, 606 (1969). 
and bargaining for it contains a built-in bias toward protracted litigation, and fails to protect employee free choice against union coercion as well as an election does.

\section{An Alternative}

\section{A. From Cards to Elections}

The problems inherent in authorization cards suggest that the Board should shift away from reliance on cards and toward reliance on elections. The Board apparently attempted such a shift in Wilder Manufacturing Co. ${ }^{94}$ The Board refused to recognize the cards, hoping to force a union that desired recognition to petition for an election. ${ }^{95}$ The Truck Drivers court thought the Board had gone too far. ${ }^{96}$ Holding that the employer should not be allowed to ignore the cards, it offered the suggestion that he should be required to petition for an election. Even if that holding is left undisturbed by the Supreme Court, the Board should take a more active role in these situations, rather than invariably leaving the duty to file a petition with either the union or the employer. Experience has shown that neither is willing to petition, always inviting the other to do so in a continual Alphonse and Gaston routine. ${ }^{97}$ Therefore, when a dispute in which neither party has petitioned for an election reaches the Board via the union's filing of a refusal-to-bargain charge, the Board itself should order an election immediately.

Of course, if the NLRB entered the dispute too early, the parties would be prevented from settling their differences on their own. Thus, the Board should establish standards to define when it will order an election sua sponte. At a minimum, the Board should not intervene unless: (1) a union has claimed a card majority and requested recognition and bargaining from the employer; (2) the employer has refused recognition and has declined to submit the cards to an impartial third party for authentication or to agree on some other method of determining union support; ${ }^{88}$ (3) both the employer and the union have refused to petition for an election; and (4) the union has filed refusalto-bargain charges. ${ }^{99}$ Then the Board may resolve the question by

94. 81 L.R.R.MT. 1039 (1972).

95. Id. at 1041 .

96. Truck Drivers Local 413 v. NLRB, 487 F.2d 1099 (D.C. Cir. 1973).

97. See, e.g., Wilder Mfg. Co., 81 L.R.R.M. 1039 (1972); Linden Lumber Div., Summer \& Co., 190 N.L.R.B. 718, 77 L.R.R.M. 1305 (1971).

98. See Wilder Mfg. Co., 81 L.R.R.M. 1039 (1972); Snow \& Sons, 134 N.L.R.B. 709 (1961).

99. 29 U.S.C. $\S 158(a)(5)(1970)$. 
ordering an election. In effect, a refusal-to-bargain charge would be treated as a petition for an election.

A Board-ordered election "retains primary emphasis on the election process." 100 It avoids the necessity of determining union support in lengthy unfair labor practice litigation, which often takes the form of calling most of the employees to the stand to testify about coercion or misrepresentation in the drive. ${ }^{101}$ The time lapse between card drive and trial dulls memories and alters perceptions, making the process even less reliable than the cards themselves. If the NLRB ordered an election on its own early in the process, a better method of determining employee sentiment would supersede the adjudicative process and render it unnecessary. It would protect the employees' right to designate a bargaining representative. It would also provide a basis on which to hold the employer to an objective determination of the union's status, thus extricating the Board from the good faith thicket.

The proposed solution facilitates another goal. The Act contemplates that the private parties involved will order their relations through bargaining and persuasion, and a limited amount of economic force. ${ }^{\mathbf{1 0 2}}$ The Act establishes a procedural framework, ${ }^{103}$ with some substantive limitations on the use of economic force, ${ }^{104}$ within which private persons conduct their relations. The government intervenes only when one side violates the procedural requisites or the outer limits on the use of economic force, or when private ordering breaks down. In the case of an authorization card dispute, one or all of these may have happened. ${ }^{105}$

If the Board treats a refusal-to-bargain charge as a petition for election, it would not be resolving the dispute exactly as presented. On the face of it, this action might seem to deny private ordering. In a

100. Truck Drivers Local 413 v. NLRB, 487 F.2d 1099, 1112 (D.C. Cir. 1973).

101. See, e.g., Engineers \& Fabricators, Inc. v. NLRB, 376 F.2d 482 (5th Cir. 1967); NLRB v. Gotham Shoe Mfg. Co., 359 F.2d 684 (2d Cir. 1966); NLRB v. Cumberland Shoe Corp., 35I F.2d 917 (6th Cir. 1965); NLRB v. Koehler, 328 F.2d 770 (4th Cir. 1964). The trial becomes, in effect, a public election. Any unfair labor practices of the employer that might invalidate an election can have an effect at trial as well. The employees are aware of the purpose of their testimony, and may tend to slant their perceptions of events that happened long before trial as a reaction to employer's threats or promises that invalidated the election.

102. 29 U.S.C. $\$ 151$ (1970); H. Wellington, LABor and the Legal Process 45 (1968); Lesnick, supra note 76, at 867. See S. REP. No. 573, 74th Cong., Ist Sess. 2 (1935).

103. See S. Rep. No. 573, 74th Cong., lst Sess, 2 (1935). 29 U.S.C. \$ 159 (1970) establishes procedures for conducting elections; 29 U.S.C. $\$ 160$ (1970) establishes procedures for adjudicating allegations of violations of $\S 158$, which in turn establishes procedural requisites and definitions of the relations between employer and union, such as the duty to bargain.

104. 29 U.S.C. $\$ 158(1970)$.

105. Id. $\S 160(1970)$. 
deeper sense, however, the suggested approach affirms the private function. Unfair labor practice litigation, which is the ordinary consequence of a refusal-to-bargain charge, makes the Board a mediator deciding the substantive issues in a private dispute, precisely what the authors of the Act sought to avoid. ${ }^{106}$ If instead the Board orders an election, it essentially washes its hands of the substantive part of the dispute, dissolves the stalemate, and establishes a procedural framework in which the private parties may continue or resume their own relations in order to settle the dispute. ${ }^{107}$

One might still argue that the Board's attempt in Wilder Manufacturing Co. to encourage an election by not recognizing the cards ${ }^{108}$ promotes private ordering better than the alternative proposed here. ${ }^{100}$ Indeed, it does favor private ordering, but to the point where the employer is allowed to escape the commands of the Act. ${ }^{110}$ To remedy this situation, a Board-ordered election is a less intrusive measure than the suggestion on remand in Truck Drivers that the Board put the employer to some test of good faith. ${ }^{111}$

One might still object to the Board's taking such a step on the grounds that it does not have specific statutory authority to order an election where the parties have not petitioned for one. Yet there is nothing in the statute to prevent such an order. In fact, the Act might be found to give support to the measure in three ways.

First, the statute gives the Board broad powers to effectuate the policies of the Act.112 Section 10(a) $)^{113}$ authorizes the Board "to prevent any person from engaging in any unfair labor practice ${ }^{114}$ affecting. commerce." In ordering an election and determining union status, the Board may well prevent an employer from committing an $8(a)(5)^{115}$ violation, refusing to bargain when he has an obligation to do so.

Second, though there is no explicit statutory authority for the Board to order an election without a petition from an employer or a union, if the Board makes it known that any 8(a)(5) charge based on a card majority will be treated first as a petition for an election, then an 8(a)(5) charge is a petition for an election, and it supports the Board's

106. S. REP. No. 573, 74th Cong., 1st Sess. 2 (1935).

107. Id.

108. 81 L.R.R.M. 1039 (1972).

109. Id. at $1040-41$.

110. Truck Drivers Local 413 v. NLRB, 487 F.2d 1099, 1111-13 (D.C. Cir. 1973).

111. Id. at 1111 .

112. 29 U.S.C. $\$ 160$ (1970).

113. Id. \$160(a).

114. See id. \$158.

115. Id. $\$ 158(a)(5)$. 
order. Of course, this would not bar later litigation on the refusal-tobargain issue, if the election process totally breaks down.

Finally, the Board might justify its order for an election as an investigative tool, authorized by section $11(1) \cdot{ }^{116}$ The Board might find that since no other investigative method equals a Board-conducted election in determining employee sentiment, it prefers an election to the current practice of calling employees to testify regarding union support and the card drive. ${ }^{117}$

\section{B. Safeguarding the Election Process}

The proposed solution poses no problems where both the employer and the union have not committed election-voiding unfair labor practices during the card drive or election campaign. Where the employer has misbehaved, on the other hand, NLRB $v$. Gissel Packing Co. ${ }^{118}$ validated the issuance of a bargaining order based on a card majority. This remedy is less than satisfactory, however. To the extent that the cards are unreliable, the remedy runs the danger of ignoring the genuine free choice of the employees. Thus the NLRB should hold to the practice recommended in the preceding section, ordering an election wherever possible, especially where only the potential of future unfair labor practices which might void an election exists. ${ }^{110}$

In such cases the Board's traditional remedies are useful-remedies such as a cease and desist order, ${ }^{120}$ posting or mailing of notices, ${ }^{121}$ and a cooling-off period between the time when the unfair labor

116. 29 U.S.C. $\$ 161(1)(1970)$.

117. The NLRB could determine an appropriate bargaining unit for the election it orders in the same manner as now, except that when ordering an election, the Board would have to request the employer and the union to submit definitions of an appropriate bargaining unit. If there is a contest, it should provide no greater delay or problems than under current procedures. See generally C. Summers \& H. WELlington, LABor LAW 5l1-48 (1968).

118. NLRB v. Gissel Packing Co., 395 U.S. 575, 610-16 (1969).

119. Only in the most severe cases should the Board resort to the bargaining order remedy. See NLRB v. Gissel Packing Co., 395 U.S. 575, 613-14 (1969); J.C. Penney Co., Inc. v. NLRB, 384 F.2d 479, 485-86 (10th Cir. 1967); United Steelworkers of Americi v. NLRB, 376 F.2d 770 (D.C. Cir. 1967); Bok, supra note 19, at 134-39. In such cases, the Board implicitly concludes that no amount of remedial action will undo the damage done by the employer's unfair labor practices.

120. For an example of a cease and desist order, see Pacific Abrasive Supply Co., 182 N.L.R.B. 329, 341-42 (1970). The cease and desist order, however, may be of littlc value because a transgressing employer is subjected to an ineffective penalty-he is simply ordered to bargain with the union. Cf. Note, The Ex.Cello and Tiidee Products Cases-Continuing Controversy Over the Make-Whole Remedy in Refusal to Bargain Cases, 19 KAN. L. REv. 325, 332 (1971) (retroactively negotiated make-whole remedy).

121. For an example of a notice, see Pacific Abrasive Supply Co., 182 N.L.R.B. 32y, $342-43$ (1970). Official notices may give the union a small psychological boost, quict cmployee fears of employer retaliation, and discredit future employer threats designed to frighten away or co-opt union support. 
practices were committed and the time of the election. ${ }^{122}$ The Board has an additional weapon authorized by the Act that it has used only sparingly; it can seek an injunction under section $10(j)^{123}$ against the respondent in an unfair labor practice proceeding. These four remedies combined could serve to deter employer misconduct and thereby protect the election process as a means of determining employee free choice.

\section{Toward More Reliable Cards}

If employer misconduct has nevertheless been so severe as to preclude a fair election even with the strongest corrective measures, ${ }^{124}$ then the Board has no choice but to use the next best method for determining employee sentiment. ${ }^{125}$ In most cases, that will be the cards, sometimes supported by other evidence, such as a recognitional strike $^{126}$ or a poll of employees. ${ }^{127}$

Reliance on the cards in those situations need not raise any problems if the Board promulgates rules to increase the reliability of the cards and to protect employees in the solicitation process. ${ }^{128}$ The rules

122. Pollitt, NLRB Re-Run Elections: A Study, 41 N.C. L. REv. 209 (1963), found that certain unfair labor practices, such as threats to close a plant, are more effective (i.e., they destroy election conditions for a longer period of time than others) and that if a rerun is held too soon after the election before the effects of the unfair labor practices have worn off, the chances for a changed result are not good.

123. 29 U.S.C. $\$ 160(j)(1970)$. "Would not an injunction with the sanctions attendant thereto more adequately fulfill the aims of protecting employee-free choice $[s i c]$, and at the same time cause no untoward benefit to either the employer or union:" Rains, supra note 19, at 230. Authorization card cases present ideal circumstances for the $\$ 10(j)$ injunction. 29 U.S.C. $\$ 160(j)(1970)$. The Senate Report on the Taft-Hartley Act recommended injunctions as a speedy way to preserve the status quo while the NLRB's slower adjudicative processes settled the underlying dispute. S. REP. No. 105, 80th Cong., Ist Sess. 8, 27 (1947).

The Supreme Court has never considered the extent of the district court's power to issue a $I 0(\mathrm{j})$ injunction; the only case on this issuc that reached the Court was mooted prior to decision. McLeod v. General Elec. Co., 257 F. Supp. 690 (S.D.N.Y. 1966), rev'd, 366 F.2d 847 (2d Cir. 1966), stay granted, 87 S. Ct. 5 (Harlan, J.), stay dissolved, judgment vacated as moot, 385 U.S. 533 (1967). The circuits have disagreed on the standard to be used to determine whether an injunction is appropriate. The Eighth Circuit's standard is strict, but an injunction would nonetheless be appropriate in the case of potential election-voiding unfair labor practices by the employer. Minnesota Mining \& Mfg. Co. v. Morton, 385 F.2d 265, 270 (8th Cir. 1965). Other circuits have taken a more liberal view which would clearly permit the use of an injunction in these cases. Boire v. International Bhd. of Teamsters, $479 \mathrm{~F} .2 \mathrm{~d} 778$ (5th Cir. 1973); UAW v. NLRB, 449 F.2d 1046 (D.C. Cir. 1971) (per curiam); Angle v. Sacks, 382 F.2d 655 (10th Cir. 1967).

124. NLRB v. Gissel Packing Co., 395 U.S. 575, 613-14 (1969).

125. See Sheinkman, supra note 86, at 328; NLRB v. Schon Stevenson \& Co., Inc., 386 F.2d 551, 554, 556-57 (4th Cir. 1967) (Sobeloff, J., concurring specially). See also NLRB v. Gissel Packing Co., 395 U.S. 575, 614 (1969).

126. See, e.g., Truck Drivers Local 413 y. NLRB, 487 F.2d 1099, $1108-09$ (D.C. Cir. 1973).

127. NLRB v. Gissel Packing Co., 395 U.S. 575, 608-09 (1969); Struksnes Constr. Co., 165 N.L.R.B. 1062, 65 L.R.R.M. 1385 (1967); Hammond \& Irving, Inc., 154 N.L.R.B. 1071 (1965). 128. Improving card reliability has been suggested, though only in broad outline, in Comment, supra note 8. 
need not be complicated. They should require that the cards be unambiguously worded and that they include a statement to the effect that the solicitor has not coerced the signer, misrepresented the purpose of the card, or instructed the signer to disregard its language. The cards should state clearly that they are revocable at any time up until the union presents a bargaining demand to the employer. ${ }^{120}$ Finally, the union should be required to notify the Board's Regional Office in order to make the drive public and inform the employer. Such notification would also permit rival unions to enter the card drive.

In addition, the Board should prevent deliberate disregard of the solicitation rules by denying a card-based bargaining order to a union that seriously violates the rules, whether or not there is employer misconduct. ${ }^{130}$ Such a rule need not penalize a union for minor errors committed by solicitors, but it would deter continued use of cards of questionable reliability by encouraging union adherence to the rules. Less stringent rules might apply when the union seeks to use cards only to support an election petition. ${ }^{131}$

Card solicitation rules might encourage employers to accept the cards as a reliable indicator of employee sentiment. Their greater reliability would justify their use to support a bargaining order where a fair election is impossible. And the rules would benefit employers willing to recognize a union on the basis of signed cards by protecting them from $\$ 8(a)(1)$ charges of restraint or coercion of the employees'

129. Though the NLRB need not prescribe the form of the cards, an acceptable card might be worded as follows:

I, (employee's name, printed), hereby designate (union) as my exclusive representative for the purposes of collective bargaining about rates of pay, wages, hours of employment, and other conditions of employment.

I sign this card without any pressure or coercion from (solicitor's name) or from any employee or union member. I understand that the card will be used to designate the union as my sole bargaining representative and that it is effective without my first voting for the union in an election. I understand further that $I$ may revoke or withdraw my signature on this card, or demand the return of this card at any time until the union presents a bargaining demand to my employer, supported by cards from a majority of the employees in my bargaining unit. I have received a copy of this card signed and dated by the solicitor in order to keep me informed of my rights and my status with the union.

For examples of card forms, see NLRB v. Gissel Packing Co., 395 U.S. 575, 583 n.4 (1969); Truck Drivers Local 413 v. NLRB, 487 F.2d 1099, 1100 n.2 (D.C. Cir. 1973); NLRB v. Cumberland Shoe Corp., 351 F.2d 917, 918 (6th Cir. 1965).

130. Cf. Laura Modes Co., 144 N.L.R.B. 1592, 54 L.R.R.M. 1299 (1963).

131. Currently, a union usually needs a 30 percent showing of support in order to file a representation petition. 1969 CCH GuIbebook to LAB. REL. I 402.4. 
right to organize and $\S 8(\mathrm{a})(2)$ charges of employer-dominated or employer-encouraged unions. ${ }^{132}$

The rules would also protect an employee's right to make an informed and uncoerced decision on whether or not to select a bargaining representative. ${ }^{133}$ The employees would have more information on the merits of unionization and of the particular union, because management would be able to mount its own campaign, pointing out the problems of unionization or of the union spearheading the drive. A rival union might serve the same function. Faced with such opposition, the union that initiated the drive would be forced to put up its best arguments.

Retaining the card drive gives the union some advantages as well. In an election, a union must gain and hold its support over a fixedlength election campaign. In a card drive, the union has more flexibility; it may continue the drive as long as it needs to gain a majority. The union can thus time its recognition and bargaining demand most advantageously. Finally, a card drive does not bar another drive for a year if the union is unsuccessful, as does an election.

\section{Conclusion}

Employers and unions have waged a war of attrition over authorization cards for long enough. The delays caused by nonrecognition or by costly litigation only hurt the employees, who are caught in the crossfire. Authorization cards should reflect employee free choice far better than they now do, and elections, long called the "preferred route" for the designation of a bargaining representative, should be employed far more readily. As this Note has suggested, there do exist rules and procedures that the National Labor Relations Board could adopt to promote those ends; Linden Lumber ${ }^{134}$ presents the Supreme Court with an important opportunity to see that the Board does so.

132. 29 U.S.C. $\$ \S 158(a)(1), 158(a)(2)(1970)$.

133. See notes 23, 24 supra.

134. Linden Lumber Div., Summer \& Co. v. NLRB, cert. granted, 94 S. Ct. 1967 (1974). 